\title{
Resilience in carbonate production despite three coral bleaching events in 5 years on an inshore patch reef in the Florida Keys
}

\author{
Derek P. Manzello ${ }^{1} \cdot \operatorname{lan}$ C. Enochs ${ }^{1,2} \cdot$ Graham Kolodziej $^{1,2} \cdot$ Renée Carlton $^{3} \cdot$ Lauren Valentino $^{1,2}$
}

Received: 14 March 2018 / Accepted: 23 April 2018 / Published online: 8 May 2018

(c) The Author(s) 2018

\begin{abstract}
The persistence of coral reef frameworks requires that calcium carbonate $\left(\mathrm{CaCO}_{3}\right)$ production by corals and other calcifiers outpaces $\mathrm{CaCO}_{3}$ loss via physical, chemical, and biological erosion. Coral bleaching causes declines in $\mathrm{CaCO}_{3}$ production, but this varies with bleaching severity and the species impacted. We conducted census-based $\mathrm{CaCO}_{3}$ budget surveys using the established ReefBudget approach at Cheeca Rocks, an inshore patch reef in the Florida Keys, annually from 2012 to 2016. This site experienced warm-water bleaching in 2011, 2014, and 2015. In 2017, we obtained cores of the dominant calcifying coral at this site, Orbicella faveolata, to understand how calcification rates were impacted by bleaching and how they affected the reef-wide $\mathrm{CaCO}_{3}$ budget. Bleaching depressed $O$. faveolata growth and the decline of this one species led to an overestimation of mean $\left( \pm\right.$ std. error) reef-wide $\mathrm{CaCO}_{3}$ production by $+0.68( \pm 0.167)$ to $+1.11( \pm 0.236) \mathrm{kg} \mathrm{m}^{-2}$ year $^{-1}$ when using the static ReefBudget coral growth inputs. During non-bleaching years, the ReefBudget inputs slightly underestimated gross production by $-0.10( \pm 0.022)$ to $-0.43( \pm 0.100) \mathrm{kg} \mathrm{m}^{-2}$ year $^{-1}$. Carbonate production declined after the first year of back-to-back bleaching in 2014, but then increased after 2015 to values greater than the initial surveys in 2012. Cheeca Rocks is an outlier in the Caribbean and Florida Keys in terms of coral cover, carbonate production, and abundance of $O$. faveolata, which is threatened under the Endangered Species Act. Given the resilience of this site to repeated bleaching events, it may deserve special management attention.
\end{abstract}

\section{Introduction}

Much of the ecosystem function of coral reefs is directly linked to their three-dimensional structure (Enochs and Manzello 2012; Graham and Nash 2012). Calcium carbonate $\left(\mathrm{CaCO}_{3}\right)$ production by corals and other calcifiers (e.g. crustose coralline algae, Halimeda, bryozoans, etc.) must

Responsible Editor: R. Hill.

Reviewed by K. Morgan and an undisclosed expert.

Derek P. Manzello

Derek.Manzello@noaa.gov

1 Atlantic Oceanographic and Meteorological Laboratories (AOML), NOAA, 4301 Rickenbacker Cswy., Miami, FL 33149, USA

2 Cooperative Institute for Marine and Atmospheric Studies, Rosenstiel School of Marine and Atmospheric Science, University of Miami, 4600 Rickenbacker Cswy., Miami, FL 33149, USA

3 Khaled bin Sultan Living Oceans Foundation, Landover, MD, USA exceed $\mathrm{CaCO}_{3}$ loss due to physical, chemical, and biological erosion for coral reef frameworks to persist (Glynn and Manzello 2015). Climate change and ocean acidification (OA) will reduce the production of $\mathrm{CaCO}_{3}$ by corals via mortality from bleaching, as well as depressed coral calcification from sub-lethal thermal stress and decreasing carbonate saturation state (Glynn 1988; Chan and Connolly 2013; Cantin and Lough 2014; Perry and Morgan 2017). Additionally, experimental studies suggest that OA will accelerate coral reef bioerosion and dissolution, possibly leading to net erosion and/or dissolution of reefs globally by the end of the century (Tribollet et al. 2009; Wisshak et al. 2012; ReyesNivia et al. 2013; Silbiger et al. 2014; Enochs et al. 2015, 2016a; Eyre et al. 2018).

The $\mathrm{CaCO}_{3}$ budget of coral reefs is difficult to measure as many different organisms are involved in the production of $\mathrm{CaCO}_{3}$ and its breakdown. Perry et al. (2012) developed a rapid, census-based $\mathrm{CaCO}_{3}$ budget monitoring tool for Caribbean coral reefs, termed ReefBudget. Using this method, Perry et al. (2013) showed that $\mathrm{CaCO}_{3}$ production has declined to $50 \%$ below historical averages across the Caribbean, and more than a third of the 101 sites surveyed 
(37\%) were net erosional (Perry et al. 2013). Additionally, by applying the ReefBudget method, Enochs et al. (2015) found that $89 \%$ of reefs in the Florida Keys were net erosional. In the Florida Keys, net erosion rates ranged from -0.43 to $-1.6 \mathrm{~kg} \mathrm{~m}^{-2}$ year $^{-1}$, whereas in the wider Caribbean these were -0.14 to $-1.77 \mathrm{~kg} \mathrm{~m}^{-2}$ year $^{-1}$ (Perry et al. 2013; Enochs et al. 2015). Overall, coral cover has declined by about $80 \%$ since the 1970 s in the Caribbean and reefs are losing three-dimensional structure (Gardner et al. 2003; Alvarez-Filip et al. 2009). The decline in coral cover is the primary driver of these reefs presently being net erosional, and the loss of coral has been a result of coral bleaching, disease, overfishing, and other local-scale factors like land-based sources of pollution (Williams and BunkleyWilliams 1990; Aronson and Precht 2001; Pandolfi et al. 2005). Given that many Caribbean reefs are at, or are close to $\mathrm{CaCO}_{3}$ budget neutral, termed "accretionary stasis", there is a concern that the persistence of architecturally complex reef framework structures is in jeopardy (Perry et al. 2013). Three-dimensional, architecturally complex reef frameworks are vital to reef ecosystem function, trophodynamics, and the high biodiversity of coral reefs (Enochs and Manzello 2012; Graham and Nash 2012).

The National Oceanic and Atmospheric Administration's Coral Reef Conservation Program recently instituted the National Coral Reef Monitoring Program (NCRMP) (NOAA Coral Program 2014). The goal of NCRMP is to monitor the status and trends of US reefs, including climate change, OA, and the resultant ecosystem impacts. As part of NCRMP, ReefBudget surveys are being conducted at select sites in the Caribbean where high-accuracy and high-precision measurements of carbonate chemistry are taking place. The impetus is to understand how the organisms that drive the $\mathrm{CaCO}_{3}$ budget change through time and are impacted from other disturbances such as thermal stress. This will help tease out the potential impacts from OA versus the other stressors that impact the population dynamics of key taxa in the carbonate budget of coral reefs.

Annual $\mathrm{CaCO}_{3}$ budget surveys have been conducted at Cheeca Rocks, an inshore patch reef in the Florida Keys, since 2012 (Fig. 1). In the summers of 2014 and 2015, mass coral bleaching events impacted the entire Florida Reef Tract (Fig. 2), the sixth and seventh Florida Keys-wide event since 1987. A localized bleaching event also took place at Cheeca Rocks in the summer of 2011 due to anomalously warm waters impacting inshore reef environments (Manzello et al. $2015 \mathrm{a}, \mathrm{b})$. This paper reports on the year-to-year variability in $\mathrm{CaCO}_{3}$ cycling from 2012 to 2016. Particular focus is given to the impacts of bleaching on $\mathrm{CaCO}_{3}$ production in 2011, 2014 and 2015 measured from coral cores of the dominant carbonate-producing coral species, Orbicella faveolata, that were collected in 2017 . We compare and contrast the reef-wide carbonate production estimates using the

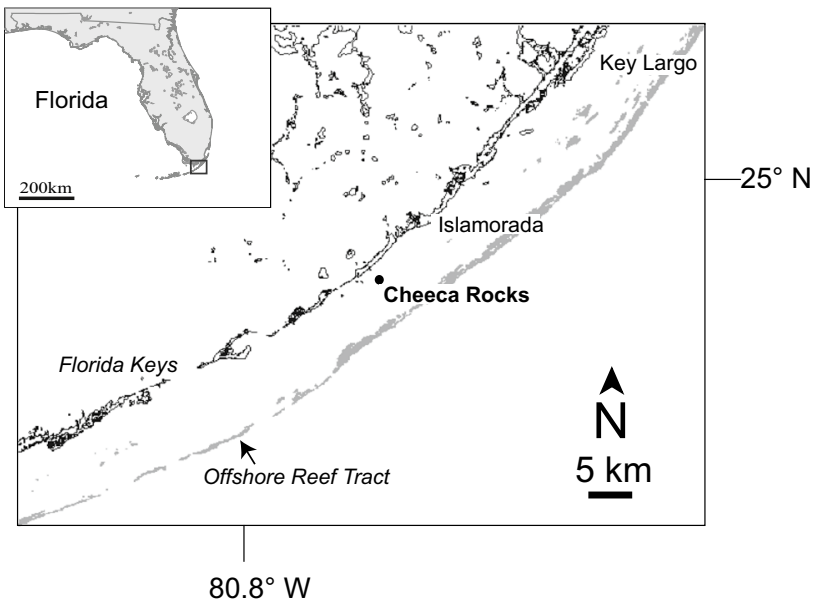

Fig. 1 Map showing location of Cheeca Rocks patch reef, Florida Keys, USA. Gray is offshore reef tract

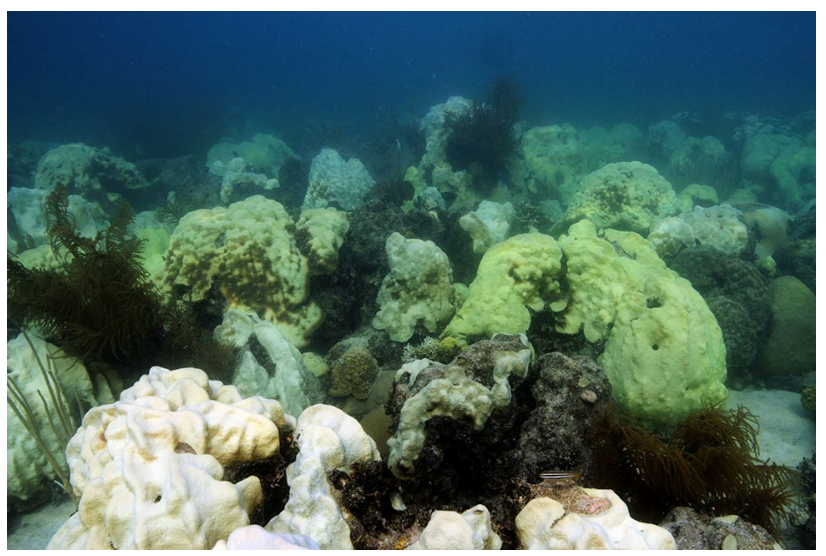

Fig. 2 Photograph of coral bleaching at Cheeca Rocks in September 2014. This image represents the high abundance of Orbicella faveolata at this site, as well as the severity of bleaching in 2014

default ReefBudget inputs for coral growth to those using the locally measured calcification rates for the dominant carbonate producer. These findings highlight the benefits of using local rate data where possible, as proposed in the original ReefBudget methodology.

\section{Methods}

In May 2012, six permanent 10-m transects were established by hammering rebar into the substrate and have been surveyed annually at Cheeca Rocks $(24.8977 \mathrm{~N}, 80.6182 \mathrm{~W})$, which is a shallow (depth range 2-6 m) inshore patch reef in the Florida Keys, adjacent to Islamorada (Fig. 1). Carbonate budget surveys followed the ReefBudget protocols described by Perry et al. (2012). In brief, a chain transect 
survey is conducted along each $10-\mathrm{m}$ linear transect whereby a flexible chain is laid upon the reef and all the organisms and substrate types underlying the chain are counted. Corals are identified to species, while other major taxa are categorized based on functional group, including crustose coralline algae, Halimeda, and sponge.

Three different types of surveys document the prevalence of bioeroding taxa. First, the surface area of clionaid sponge cover is determined for $0.5 \mathrm{~m}$ on either side of each $10-\mathrm{m}$ linear transect using a quadrat. Second, the test diameter of each urchin species encountered within $1 \mathrm{~m}$ of either side of each 10-m transect is measured using hand-held calipers. Lastly, $30-\mathrm{m}$ by $4-\mathrm{m}$ belt transects $(n=10)$ are conducted to measure parrotfish abundances across the six sites. Parrotfish are identified to species, phase, and size class according to the ReefBudget methodology (Perry et al. 2012).

The $\mathrm{CaCO}_{3}$ budget model at Cheeca Rocks was first parameterized using the default ReefBudget inputs, and then by inputting site-specific coral growth data from $5-\mathrm{cm}$ diameter $\times 10-\mathrm{cm}$-long cores of Orbicella faveolata $(n=6$, 2-3 m water depth) that were collected using a pneumatic hand-drill in May 2017. Six additional cores for which data were published in Manzello et al. (2015a) provided additional growth data from 2012 to 2014 . As such, the growth data from 2012 and 2013 represent the means of 12 cores, 2014 represents 8 cores, and 2015-2016 the recent six cores. The default ReefBudget inputs represent averages from a meta-analysis of multiple growth studies for each species of coral and bioeroder (Perry et al. 2012). Finally, the $\mathrm{CaCO}_{3}$ budget model was also parameterized by assuming that all coral species at this site had the same growth dynamics as $O$. faveolata relative to the default ReefBudget values. For example, calcification of $O$. faveolata was $81.8 \%$ of the
ReefBudget value in 2012 (Table 1), so we assumed every coral species' calcification rates were $81.8 \%$ of the ReefBudget input in 2012.

Coral cores were analyzed using a Siemens Somatom Volume Zoom spiral computerized tomography (CT) Scanner at $0.1 \mathrm{~mm}$ resolution. Density measurements were made along the growth axis in the CT images using Amira software (FEI Visualization Sciences Group, Massachusetts, USA). Density $\left(\mathrm{g} \mathrm{cm}^{-3}\right)$ was determined from grayscale values by linear regression of coral standards of known density as previously described (Groves et al. 2018). Linear extension $\left(\mathrm{cm}\right.$ year $^{-1}$ ) was determined by measuring the distance between annually repeating high-density bands using the Coral X-radiograph Densitometry System (CoralXDS) (Helmle et al. 2002). Calcification rates $\left(\mathrm{g} \mathrm{cm}^{-2}\right.$ year $\left.^{-1}\right)$ were calculated as the product of density and linear extension. For simplicity in reporting, we pooled $O$. faveolata and Orbicella annularis into one category labelled "Orbicella annularis species complex" because for some of the smaller colonies it was not possible to differentiate between these two species. $O$. faveolata accounted for $88-96 \%$ of the $O$. annularis spp. encountered from 2012 to 2016, while $O$. annularis made up the remainder. The $O$. faveolata growth data from the cores were only input into the carbonate budget model for the confirmed $O$. faveolata colonies and not any other $O$. annularis species.

The carbonate budget surveys took place in mid-summer, generally July, thus it was assumed the coral growth rates inputted into the model were integrated over the past year. For example, for surveys in 2014, the coral growth data input integrated the growth measured from the time of high-density band formation in 2013 to high-density band formation in 2014. High-density band formation in this species occurs

Table 1 Mean $\left( \pm\right.$ SEM) linear extension $\left(\mathrm{cm} \mathrm{year}^{-1}\right)$, skeletal density $\left(\mathrm{g} \mathrm{cm}^{-3}\right)$, and calcification $\left(\mathrm{g} \mathrm{cm}^{-2}\right.$ year $\left.{ }^{-1}\right)$ of Orbicella faveolata at Cheeca Rocks from 2012 to 2016

\begin{tabular}{llll}
\hline Year & Linear extension & Skeletal density & Calcification \\
\hline 2012 & $0.72(0.077)$ & $1.31(0.045)$ & $0.96(0.122)$ \\
2013 & $1.07(0.089)$ & $1.24(0.050)$ & $1.30(0.095)$ \\
2014 & $1.03(0.058)$ & $1.17(0.047)$ & $1.19(0.076)$ \\
2015 & $0.62(0.052)$ & $1.35(0.042)$ & $0.85(0.086)$ \\
2016 & $0.67(0.080)$ & $1.32(0.082)$ & $0.86(0.064)$ \\
\hline Year & Extension $\%$ & Density (\%) & Calcification (\%) \\
\hline 2012 & 85.1 & 94.1 & 81.8 \\
2013 & 126.8 & 89.2 & 111.1 \\
2014 & 121.9 & 84.0 & 102.0 \\
2015 & 73.9 & 97.2 & 72.3 \\
2016 & 79.8 & 94.8 & 73.4 \\
\hline
\end{tabular}

Values also expressed as a percentage of the default ReefBudget value for this species (ReefBudget values for O. faveolata: Ext. $=0.842 \mathrm{~cm}$ year $^{-1}$; density $=1.39 \mathrm{~g} \mathrm{~cm}^{-3}$; calcification $1.17 \mathrm{~g} \mathrm{~cm}^{-2}$ year $^{-1}$ )

SEM standard error of the mean 
in the late summer (Hudson et al. 1976). The impacts of bleaching in 2014 and 2015 thus manifested in the 2015 and 2016 carbonate budget output. Statistical analyses were performed using Sigma-Plot 12.

\section{Results}

The extension rates of $O$. faveolata were significantly impacted by warm-water bleaching in 2011, 2014, and 2015 (Fig. 3, Tables 1, 2). Cheeca Rocks experienced 7.7 degree heating weeks (DHWs) in 2014 and 9.5 in 2015 (Gintert et al. 2018). DHWs are a measure of the magnitude and duration of sea temperatures $\geq 1{ }^{\circ} \mathrm{C}$ above the maximum monthly mean temperature and are the most often used metric of thermal stress for coral reefs (Liu et al. 2006). In situ temperature data from Cheeca Rocks are not available for 2011, but for nearby Molasses Reef, DHWs were 0.9 less in 2011 relative to 2014. Cheeca Rocks and Molasses Reef have similar patterns in sea temperatures, so it is likely that the differences in magnitude of thermal stress between the three bleaching years were similar (Gintert et al. 2018). There was a significant depression in calcification in 2015 due to bleaching in 2014, but the 2016 values were not significantly different from the other years despite being noticeably depressed from bleaching in 2015 (Fig. 3). Density slightly increased after bleaching, but was not significant.

Coral cover increased $4.5 \%$ from 2012 to 2016 , but this was not significant (Fig. 4, Tables 2, 3). The O. annularis spp. complex dominated the coral community, making up 69.3-73.6\% of total cover. Siderastrea siderea, Porites astreoides, and Colpophyllia natans were the next three species with the highest cover, respectively. O. faveolata was the dominant species, accounting for $>88 \%$ of the $O$. annularis spp. measured. Both total coral cover and cover of the $O$. annularis spp. declined by $1.3 \%$ after the 2014 bleaching event (Fig. 4). Cover of O. annularis spp. was $0.5 \%$ lower in $2016(22.8 \%)$ than it was prior to bleaching (23.3\% in 2014), but still higher than it was at the beginning of monitoring in $2012(20.2 \%)$.

Gross $\mathrm{CaCO}_{3}$ production increased every year when the default ReefBudget inputs for coral calcification were used, ranging from $4.50 \pm 0.746 \mathrm{~kg} \mathrm{~m}^{-2} \mathrm{year}^{-1}$ (mean \pm std. error) in 2012 to $5.73 \pm 0.873 \mathrm{~kg} \mathrm{~m}^{-2} \mathrm{year}^{-1}$ in 2016 (Table 3, Fig. 4). O. annularis spp. were responsible for $72-80 \%$ of total production in any given year. Using the ReefBudget inputs, gross production increased by $0.17 \mathrm{~kg} \mathrm{~m}^{-2}$ year $^{-1}$ in 2015 after bleaching in 2014 despite a decline in coral cover. This was because of changes in the abundances of multiple taxa (Table 4). Despite declines in some species (O. annularis, Porites astreoides, Porites porites) there were increases in others (O. faveolata, Siderastrea siderea,
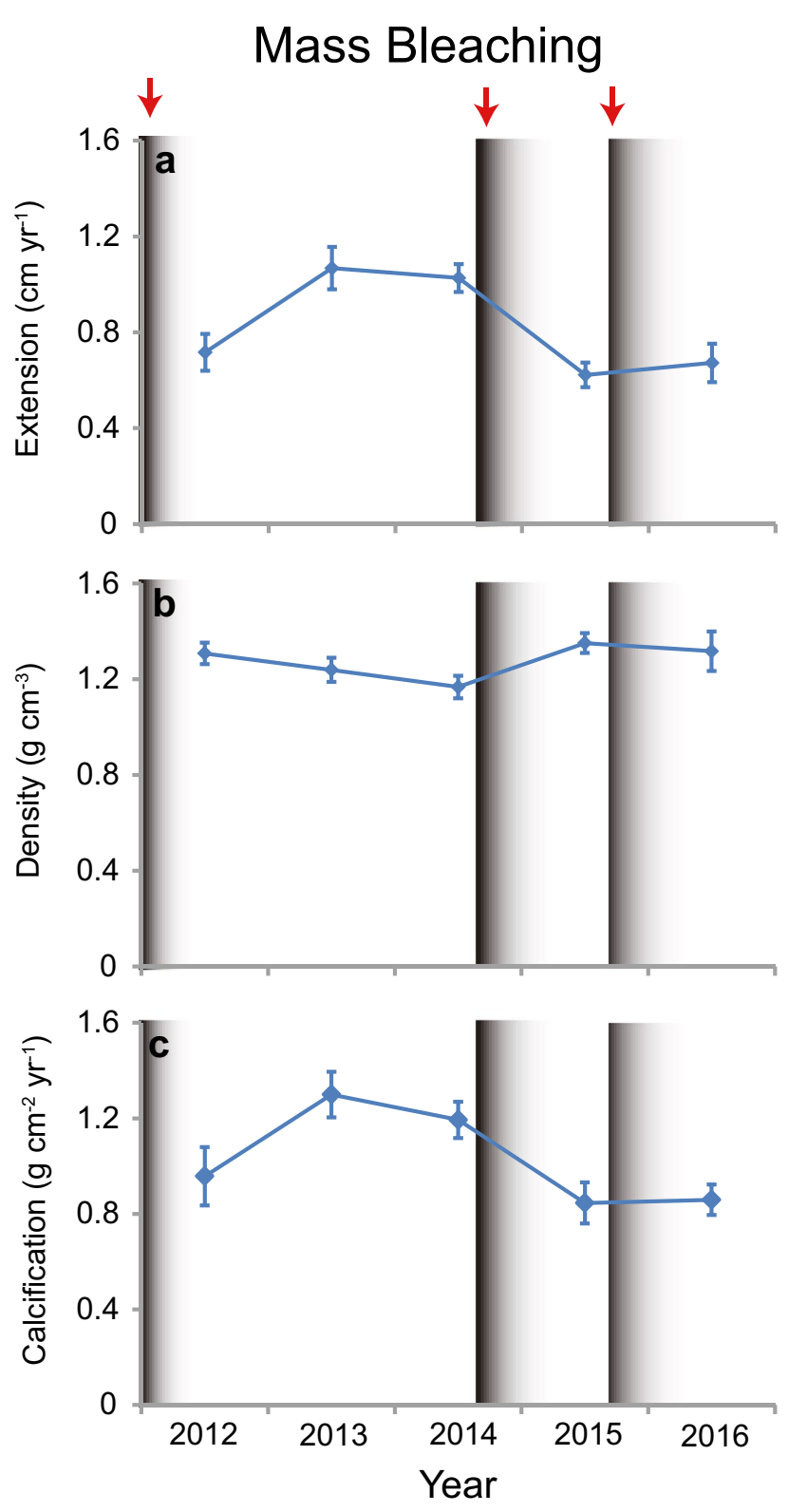

Fig. 3 Mean a linear extension, $\mathbf{b}$ density, and $\mathbf{c}$ calcification rate per year from 2012 to 2016 at Cheeca Rocks. Error bars are std. error of mean. Bleaching events in 2011, 2014, and 2015 are indicated by red arrows and shaded black bars

Stephanocoenia intersepta) that led to the slight increase in $\mathrm{CaCO}_{3}$ production.

When the locally measured calcification rates of $O$. faveolata were input into the model, gross and net carbonate production were more variable and followed a similar pattern to the calcification rates measured in the cores (Fig. 4). There were no significant differences by year for gross or net carbonate production when the core data were used despite the notable declines following bleaching (Table 2). However, there was a significant effect by year when the 
Table 2 Results of repeated measures ANOVA for $\mathrm{CaCO}_{3}$ budget parameters by year from 2012 to 2016

\begin{tabular}{|c|c|c|c|}
\hline & \multicolumn{3}{|l|}{ Calcification rate input } \\
\hline & ReefBudget & O. faveolata input & All corals \\
\hline \multicolumn{4}{|l|}{ Variable } \\
\hline \multicolumn{4}{|c|}{ Reef-wide $\mathrm{CaCO}_{3}$ production/bioerosion } \\
\hline Gross & ns & ns & ns \\
\hline Net & ns & ns & ns \\
\hline O. annularis spp. & ns & $\begin{array}{l}F=3.2, P<0.05 \\
\text { pairwise ns }\end{array}$ & $\begin{array}{l}F=3.4, P<0.05 \\
\text { pairwise } \mathrm{ns}\end{array}$ \\
\hline Coral cover $(\%)$ & ns & $\mathrm{n} / \mathrm{a}$ & $\mathrm{n} / \mathrm{a}$ \\
\hline \multicolumn{4}{|c|}{ Orbicella faveolata growth data } \\
\hline Extension & $\begin{array}{l}F=6.6, P<0.001 \\
2013>2012,2015,2016 \\
2014>2015\end{array}$ & $\mathrm{n} / \mathrm{a}$ & $\mathrm{n} / \mathrm{a}$ \\
\hline Density & ns & $\mathrm{n} / \mathrm{a}$ & $\mathrm{n} / \mathrm{a}$ \\
\hline Calcification & $\begin{array}{l}F=3.7, P<0.05 \\
2013>2015\end{array}$ & $\mathrm{n} / \mathrm{a}$ & $\mathrm{n} / \mathrm{a}$ \\
\hline \multicolumn{4}{|l|}{ Bioerosion } \\
\hline $\begin{array}{l}\text { Total } \\
\text { Bioerosion by taxa }\end{array}$ & $F=3.0, P<0.05,2014>2013$ & $\mathrm{n} / \mathrm{a}$ & $\mathrm{n} / \mathrm{a}$ \\
\hline Urchin* & $\begin{array}{l}\chi^{2}=10.6, P<0.05 \\
2016<2012\end{array}$ & $\mathrm{n} / \mathrm{a}$ & $\mathrm{n} / \mathrm{a}$ \\
\hline Parrotfish & $\begin{array}{l}F=4.8, P<0.01 \\
2014>2012,2013\end{array}$ & $\mathrm{n} / \mathrm{a}$ & $\mathrm{n} / \mathrm{a}$ \\
\hline Clionaid sponges & ns & $\mathrm{n} / \mathrm{a}$ & $\mathrm{n} / \mathrm{a}$ \\
\hline Microborers & $\begin{array}{l}F=4.1, P<0.05 \\
2016>2013,2014\end{array}$ & $\mathrm{n} / \mathrm{a}$ & $\mathrm{n} / \mathrm{a}$ \\
\hline
\end{tabular}

Tukey pairwise comparison used when ANOVA indicated significant differences between years $n s$ not significant, $n / a$ not applicable

*Data not normal, repeated measures ANOVA on ranks (Friedman test) used differences between the gross production outputs using the ReefBudget and the locally measured $O$. faveolata data were examined (Repeated Measures Analysis of Variance, $F=19.1, P<0.001$ ) (Fig. 5). The bleaching-impacted years of 2012, 2015 and 2016 were significantly different than those years at least 1 year removed from a bleaching event (2013, 2014) (Tukey post hoc tests, $P<0.05$ ). When $O$. faveolata calcification rates were impacted by bleaching, the ReefBudget inputs overestimated mean ( \pm std. error of mean) rates of gross reef calcification by $+0.68( \pm 0.167)$ in 2012 to $+1.11( \pm 0.236) \mathrm{kg} \mathrm{m}^{-2}$ year $^{-1}$ in 2015 (Fig. 5). During non-bleaching years, the ReefBudget inputs slightly underestimated (relative to the site-parameterized calcification model) gross production by $-0.10( \pm 0.022)$ to -0.43 $( \pm 0.100) \mathrm{kg} \mathrm{m}^{-2}$ year $^{-1}$. Not surprisingly, the overestimations of gross production by the ReefBudget inputs were greater when it was assumed that all the coral species at Cheeca Rocks grew in the same way as $O$. faveolata relative to the ReefBudget inputs $(F=30.7, P<0.01)$ (Fig. 5).

Parrotfish accounted for $53.2-77.6 \%$ of the total bioerosion at Cheeca Rocks, ranging from $-0.50( \pm 0.087)$ in 2012 to $-1.21( \pm 0.192) \mathrm{kg} \mathrm{m}^{-2}$ year $^{-1}$ in 2014 (Fig. 6, Table 3).
Parrotfish bioerosion was significantly greater in 2014 than the prior 2 years with rates more than doubling in a single year (Tables 2, 3). Parrotfish were mainly juvenile striped parrotfish, Scarus iserti. Microbioerosion was the second largest contributor to total bioerosion, followed by urchins in the genus Echinometra (Fig. 6). Clionaid sponge bioerosion was negligible. In 2016, after two consecutive years of bleaching, urchin bioerosion was the lowest since 2012, whereas microbioerosion was the highest (Table 3 ).

\section{Discussion}

Sublethal bleaching in 2011, 2014, and 2015 significantly impacted the extension and calcification rates of the dominant $\mathrm{CaCO}_{3}$ producer, $O$. faveolata at Cheeca Rocks, which in turn led to an overestimation of gross $\mathrm{CaCO}_{3}$ production during these bleaching-impacted years when the default coral growth rates in ReefBudget were used. This is not surprising given that the ReefBudget calcification inputs represent an average of growth rates for each species during unstressed conditions (Perry et al. 2012). Furthermore, 

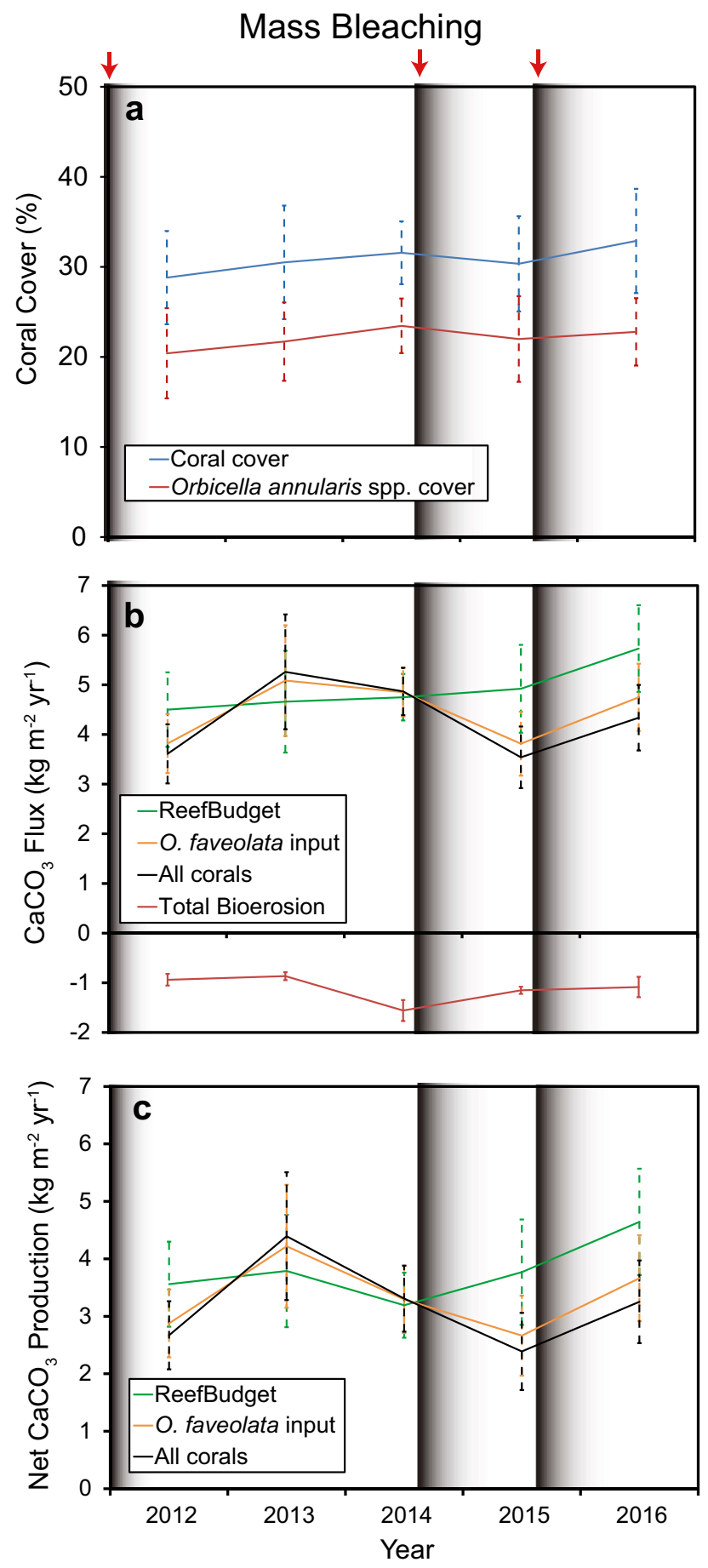

Fig. 4 Coral cover and $\mathrm{CaCO}_{3}$ flux at Cheeca Rocks from 2012 to 2016. a Percent cover of all corals (blue) and Orbicella annularis species complex (red). b Gross $\mathrm{CaCO}_{3}$ production and bioerosion (red line). c Net $\mathrm{CaCO}_{3}$ production. $\mathrm{CaCO}_{3}$ production estimates using ReefBudget input are in green, whereas production data generated with locally measured Orbicella faveolata calcification data are shown by an orange line. The black line shows production values when the same relative offset measured for the $O$. faveolata data versus the default ReefBudget value was applied to all coral species. Values are means \pm std. error of the mean coral bleaching is well known to depress coral calcification and linear extension (Cantin and Lough 2014), as has been previously shown at Cheeca Rocks (e.g., Manzello et al. $2015 \mathrm{a}, \mathrm{b})$. These data confirm the previously reported low extension and calcification after the 2011 bleaching event followed by a quick recovery in the following year (Manzello et al. 2015a). During non-bleaching years, the ReefBudget inputs tended to underestimate gross production for this site because growth rates at Cheeca Rocks for $O$. faveolata were greater than the default values (Table 1). Overall, the ReefBudget default inputs yielded gross production data that were generally in good agreement with the production rates estimated with the actual growth data when calcification of the dominant calcifier was not impaired by bleaching.

Cheeca Rocks exhibited resilience in $\mathrm{CaCO}_{3}$ production with back-to-back coral bleaching events in 2014 and 2015, despite these being the two hottest years on record (Manzello 2015; Gintert et al. 2018). Coral cover unexpectedly increased in our six transects from 2012 to 2016, despite a slight decline after the 2014 bleaching. In a companion study utilizing landscape mosaic photographic imagery of these same sites from 2012 to 2016, but incorporating a larger area per site $(10 \mathrm{~m} \times 10 \mathrm{~m})$, a similar resilience to bleaching was documented (Gintert et al. 2018). The Gintert et al. study did, however, document a $3.7 \%$ decline in coral cover as a result of the two bleaching events (from 29.2\% in 2014 to $25.5 \%$ in 2016), but bleaching prevalence, severity, and mortality were lower during the second year of bleaching despite there being greater thermal stress in 2015 . The disparity in coral cover changes over the same time frame between these two studies may be because the $\mathrm{CaCO}_{3}$ production data presented herein are parameterized by approximately 60 total linear meters of reef per year, whereas the other study surveyed $600 \mathrm{~m}^{2}$ of reef per year. Despite these differences, both studies indicate that the 2014 and 2015 bleaching events did not have an overly severe impact on the coral community at Cheeca Rocks.

This contrasts greatly with other sites that experienced high degrees of coral mortality and consequently large declines in $\mathrm{CaCO}_{3}$ production after bleaching (e.g., Glynn 1988; Perry and Morgan 2017). A recent study using the ReefBudget methodology in the Maldives found that a single bleaching event in 2016 led to a $75 \%$ decline in coral cover and $78 \%$ decline in gross carbonate production in 8 months (Perry and Morgan 2017). One explanation for these differences is that the Maldives experienced slightly greater thermal stress with a maximum of 10.4 degree heating weeks (DHW, a metric for thermal stress dosage, Liu et al. 2006) versus a maximum of 9.5 DHW at Cheeca Rocks (Fig. 7). It seems unlikely, though, that an increase of as little as $<1$ DHW would be the sole factor for such different outcomes, especially given that Cheeca Rocks experienced two consecutive bleaching events. 
Table $3 \mathrm{CaCO}_{3}$ production and bioerosion by year from 2012 to 2016

\begin{tabular}{|c|c|c|c|c|c|}
\hline $\mathrm{CaCO}_{3}$ budget metrics & 2012 & 2013 & 2014 & 2015 & 2016 \\
\hline Coral cover $(\%)$ & $28.4(4.69)$ & $29.6(6.31)$ & $31.6(3.48)$ & $30.3(5.29)$ & $32.9(5.79)$ \\
\hline O. annularis spp. cover (\%) & $20.2(4.45)$ & $21.1(4.35)$ & $23.3(3.03)$ & $22.0(4.76)$ & $22.8(3.75)$ \\
\hline O. annularis spp. $\%$ of total cover & $69.5(8.47)$ & $69.6(7.09)$ & $73.5(7.04)$ & $66.0(9.86)$ & $70.0(5.57)$ \\
\hline \multicolumn{6}{|l|}{ Gross $\mathrm{CaCO}_{3}$ production } \\
\hline \multicolumn{6}{|l|}{ ReefBudget inputs } \\
\hline Gross production & $4.50(0.746)$ & $4.66(1.022)$ & $4.75(0.467)$ & $4.92(0.869)$ & $5.73(0.873)$ \\
\hline O. annularis spp. production & $3.51(0.764)$ & $3.55(0.721)$ & $3.86(0.501)$ & $3.91(0.842)$ & $4.37(0.723)$ \\
\hline $\begin{array}{l}\text { O. annularis spp. } \% \text { of total } \\
\text { prod. }\end{array}$ & $75.3(7.24)$ & $75.6(5.98)$ & $80.0(5.53)$ & $72.2(9.85)$ & $75.1(4.49)$ \\
\hline \multicolumn{6}{|l|}{ Local $O$. faveolata data input } \\
\hline Gross production & $3.82(0.595)$ & $5.09(1.114)$ & $4.85(0.486)$ & $3.81(0.643)$ & $4.75(0.677)$ \\
\hline O. annularis spp. production & $2.83(0.599)$ & $3.98(0.819)$ & $3.96(0.521)$ & $2.81(0.605)$ & $3.39(0.450)$ \\
\hline $\begin{array}{l}\text { O. annularis spp. } \% \text { of total } \\
\text { prod. }\end{array}$ & $72.3(7.77)$ & $77.1(5.86)$ & $80.3(5.48)$ & $67.0(10.30)$ & $72.3(5.21)$ \\
\hline \multicolumn{6}{|l|}{ All corals modeled } \\
\hline Gross production & $3.61(0.595)$ & $5.26(1.157)$ & $4.89(0.478)$ & $3.54(0.621)$ & $4.34(0.660)$ \\
\hline O. annularis spp. production & $2.81(0.612)$ & $4.01(0.815)$ & $3.95(0.513)$ & $2.81(0.605)$ & $3.30(0.509)$ \\
\hline $\begin{array}{l}\text { O. annularis spp. } \% \text { of total } \\
\text { prod. }\end{array}$ & $74.9(7.28)$ & $75.7(5.94)$ & $80.0(5.53)$ & $72.1(9.94)$ & $76.0(5.04)$ \\
\hline Total bioerosion & $-0.94(0.117)$ & $-0.87(0.081)$ & $-1.56(0.211)$ & $-1.15(0.073)$ & $-1.08(0.206)$ \\
\hline \multicolumn{6}{|l|}{ Bioerosion by taxa } \\
\hline Urchin & $-0.18(0.114)$ & $-0.07(0.054)$ & $-0.12(0.105)$ & $-0.06(0.045)$ & $-0.01(0.006)$ \\
\hline Parrotfish & $-0.50(0.087)$ & $-0.56(0.120)$ & $-1.21(0.192)$ & $-0.83(0.052)$ & $-0.80(0.202)$ \\
\hline Clionaid sponges & $-0.004(0.0028)$ & $-0.005(0.0030)$ & $-0.005(0.0040)$ & $-0.001(0.0005)$ & $-0.002(0.0016)$ \\
\hline Microbioerosion & $-0.26(0.017)$ & $-0.23(0.019)$ & $-0.22(0.021)$ & $-0.26(0.027)$ & $-0.28(0.030)$ \\
\hline \multicolumn{6}{|l|}{ Net $\mathrm{CaCO}_{3}$ production } \\
\hline ReefBudget & $3.56(0.740)$ & $3.79(0.978)$ & $3.19(0.565)$ & $3.77(0.917)$ & $4.64(0.926)$ \\
\hline Local $O$. faveolata input & $2.88(0.591)$ & $4.22(1.070)$ & $3.29(0.584)$ & $2.66(0.696)$ & $3.66(0.748)$ \\
\hline All corals modeled & $2.67(0.593)$ & $4.39(1.112)$ & $3.31(0.575)$ & $2.39(0.670)$ & $3.25(0.719)$ \\
\hline
\end{tabular}

Values are means ( \pm std. error of the mean). Reef-wide production and bioerosion values are $\mathrm{kg} \mathrm{CaCO}_{3} \mathrm{~m}^{-2}$ year $^{-1}$

Table 4 Difference in $\mathrm{CaCO}_{3}$ production $\left(\mathrm{kg} \mathrm{m}^{-2}\right.$ year $\left.{ }^{-1}\right)$ before and after bleaching in 2014 when using default ReefBudget calcification inputs

\begin{tabular}{ll}
\hline Taxa & $\begin{array}{l}\Delta \mathrm{CaCO}_{3} \\
\text { production }\end{array}$ \\
\hline Orbicella faveolata & +0.55 \\
Crustose coralline algae (CCA) & +0.02 \\
Colpophyllia natans & +0.02 \\
Diploria labyrinthiformis & +0.008 \\
Siderastrea radians & +0.007 \\
Siderastrea siderea & +0.086 \\
Stephanocoenia intersepta & +0.077 \\
Orbicella annularis & -0.49 \\
Pseudodiploria strigosa & -0.003 \\
Macroalgae covered with CCA & -0.004 \\
Montastraea cavernosa & -0.002 \\
Porites astreoides & -0.073 \\
Porites porites & -0.021 \\
Net change & +0.17 \\
\hline
\end{tabular}

High mortality of corals in the genus Acropora (91\% decline in cover) was the primary driver of the large decline in gross $\mathrm{CaCO}_{3}$ production in the Maldives, as they accounted for 52-62\% of all coral carbonate production before bleaching (Perry and Morgan 2017). Acropora in Florida, much like the wider Caribbean, have undergone drastic population declines since the 1980s and were never abundant at sites like Cheeca Rocks, given the suboptimal environmental conditions (Shinn 1966; Miller et al. 2002). Cheeca Rocks is a small inshore patch reef, approximately $2 \mathrm{~km}$ from shore and 20 ha in areal extent, which experiences high and low temperature extremes, as well as increased sedimentation, turbidity and nutrients relative to offshore reefs (Lirman and Fong 2007). Sea temperatures in the summer are generally $1{ }^{\circ} \mathrm{C}$ warmer on the inshore sites, while in the winter they are usually $>1{ }^{\circ} \mathrm{C}$ cooler (Manzello et al. 2012, 2015b). For further information on specific values of sedimentation, turbidity and nutrients, see Lirman and Fong (2007). The absence of the most thermally sensitive 


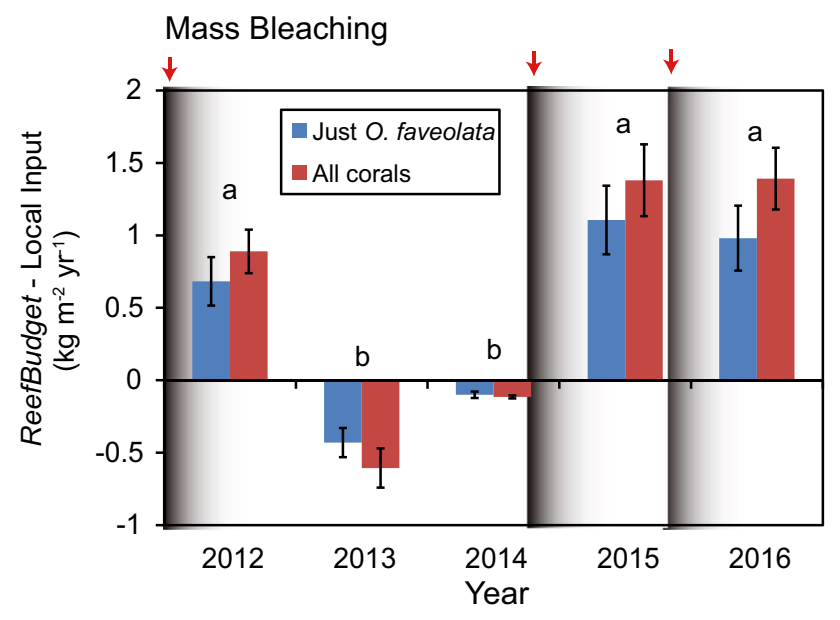

Fig. 5 Annual difference in gross carbonate production estimated by ReefBudget inputs and locally derived calcification data. Blue is when only $O$. faveolata data were used, whereas red is when all coral species were modeled. Values are means \pm std. error of the mean. Different letters denote significantly different years as indicated by Tukey post hoc comparisons

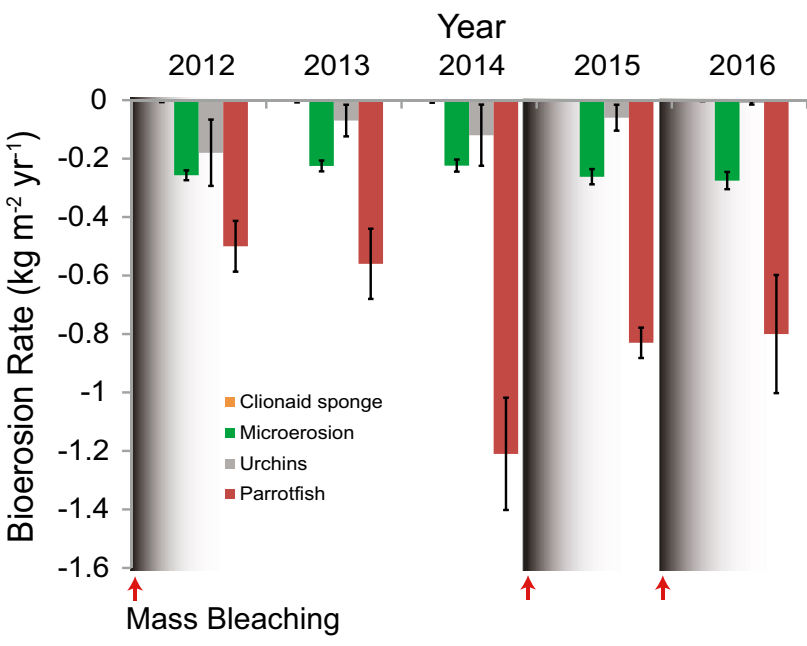

Fig. 6 Bioerosion rate by taxa from 2012 to 2016. Values are means \pm std. error of the mean

Acropora species at Cheeca Rocks is likely an additional reason for the muted response relative to the Maldives. Branching corals, like the acroporidae, tend to be more thermally sensitive than massive corals (Loya et al. 2001). Coral reefs in marginal environments like those at Cheeca Rocks have been more resilient to thermal stress events around the globe (van Woesik et al. 2012; Guest et al. 2016; Morgan et al. 2017; Gintert et al. 2018). It is unclear if marginal coral communities will continue to be resilient under greater or more frequent thermal stress, which is expected with climate change.
Bioerosion at Cheeca Rocks was dominated by parrotfish, which agrees with the other studies on Caribbean Reefs using this method (Perry et al. 2012, 2013). The decline in net $\mathrm{CaCO}_{3}$ production in the Maldives was even greater $(-157.5 \%)$ than the decline in gross production because parrotfish bioerosion increased $139.5 \%$ after bleaching (Perry and Morgan 2017). There was no obvious linkage between parrotfish abundances and bleaching at Cheeca Rocks, which is probably because the lack of coral mortality did not create new grazing space. Before the bleaching event, parrotfish abundance and bioerosion more than doubled from 2013 to 2014, but declined thereafter (Fig. 6). This was likely due to a recruitment pulse as there was a large increase in the numbers of small, juvenile striped parrotfish $(S$. iserti) in 2014 that then declined the following year. Microbioerosion played the second biggest role in bioerosion at Cheeca Rocks. Although microbioerosion significantly increased after the back-to-back bleaching events in 2014 and 2015, the increase was only +0.05 to $0.06 \mathrm{~kg} \mathrm{~m}^{-2}$ year $^{-1}$ (Table 3 ). The magnitude of this change is of limited importance to the overall carbonate budget. Urchin abundances and bioerosion were highest in the first year of monitoring and declined to very low values after the two bleaching events, but it is not clear if this is related to the bleaching events or if this just represents normal urchin population fluctuations. This is an opposite pattern to what occurred in the eastern Pacific after bleaching when urchin bioerosion became the most important factor in the carbonate budget on reefs in both Panamá and the Galápagos Islands (Glynn 1988, 1990).

Thermal stress events can negatively impact many coral reef organisms, in addition to zooxanthellate corals, including organisms with and without algal symbionts (Williams and Bunkley-Williams 1990). Thus, it is important to consider that the rates of bioerosion and calcification from organisms other than corals are also dynamic and are likely responding to temperature anomalies, as well as to increasing OA (Kennedy et al. 2013). Microbioerosion increases with temperature, OA, as well as during coral bleaching due to increased light penetration through bleached coral tissues that leads to increases in biomass of endolithic algae (Fine and Loya 2002; Tribollet et al. 2009; Reyes-Nivia et al. 2013; Enochs et al. 2016b). Clionaid sponges respond positively to OA and temperature, but zooxanthellate species are sensitive to thermal stress (Wisshak et al. 2012; Fang et al. 2014; Enochs et al. 2015a). Urchins are negatively impacted by OA and thermal stress (Uthicke et al. 2014), although the genera at Cheeca Rocks (Echinometra) showed the greatest sensitivity to OA at low temperatures (Courtney et al. 2013). Finally, parrotfish grazing increases with temperature (Smith 2008). For a holistic understanding of $\mathrm{CaCO}_{3}$ budgets, monitoring should incorporate census-based approaches like ReefBudget, routine species-specific coral calcification 
Fig. 7 Daily average sea temperatures and degree heating weeks from Cheeca Rocks and the Maldives. Data from Cheeca Rocks are in situ temperature data from Gintert et al. (2018), whereas the Maldives data are from NOAA's Coral Reef Watch (Accessed 28 Feb 2018: https ://coralreefwatch.noaa.gov/vs/ index.php)

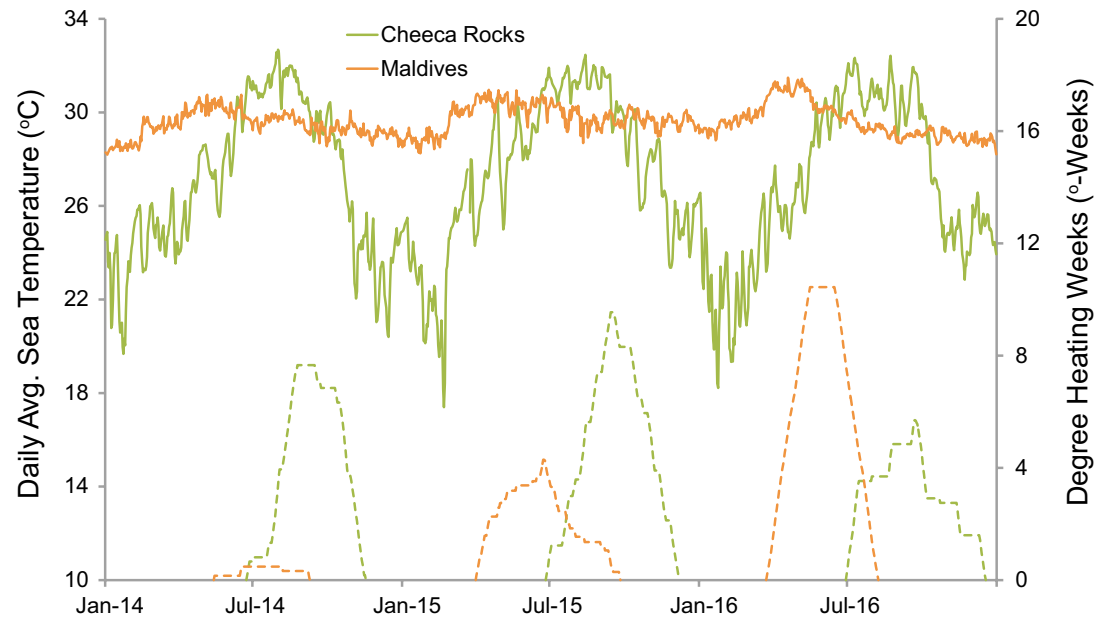

monitoring, as well as hydrochemical approaches (Courtney et al. 2016).

Cheeca Rocks is an outlier among Caribbean reefs and, most especially, among the degraded coral reefs of the Florida Keys (Ruzicka et al. 2013). The higher coral cover on the inshore reefs has been hypothesized to be due to increased resistance and/or resilience of local corals to elevated temperatures and bleaching (Kenkel et al. 2013; Kenkel and Matz 2016). It is unlikely that direct human impacts are involved as the inshore sites are closest to human population centers and land-based sources of pollution. The mechanism for this increased bleaching tolerance is unclear, but may be related to coral host and/or symbiont adaptation and/or acclimatization to high and variable temperatures, higher turbidity leading to increased feeding, and/or bleachingmitigating environmental factors (lower light) (Lirman and Fong 2007). The minimum coral cover we measured (28.4\% in 2012) was higher than $91 \%$ of the 101 individual transects measured across the Bahamas, Cayman Islands, Belize, and Bonaire by Perry et al. (2013). The lowest mean gross carbonate production at Cheeca Rocks using both the default ReefBudget and local inputs during non-bleaching years was higher than $76 \%$ of the transects occupied by Perry et al. (2013). Even the minimum gross production value using the bleaching-impacted local values were still greater than $64 \%$ of the Perry et al. (2013) sites. The gross and net rates of production at Cheeca Rocks are the highest measured to date for Florida (Enochs et al. 2015). The O. annularis spp. complex made up $67-80.3 \%$ of the carbonate production and 66-73.5\% of the total coral cover at Cheeca Rocks from 2012 to 2016. These species are listed as threatened under the Endangered Species Act (ESA) (Brainard et al. 2011). Despite 2014 and 2015 being the two warmest years on record in the Florida Keys, these two bleaching events did not have a clear, long-term impact on $\mathrm{CaCO}_{3}$ production at Cheeca Rocks. This site may be a refuge for the ESAlisted $O$. annularis spp. and, in particular, $O$. faveolata, and deserving of special protection by the Florida Keys National Marine Sanctuary.

Acknowledgements The authors thank NOAA's Coral Reef Conservation Program and Ocean Acidification Program for funding this work as part of the National Coral Reef Monitoring Program. We thank the Florida Keys National Marine Sanctuary for their support of this work (Permit nos. FKNMS-2011-160 and FKNMS-2016-120). J. Delaney of FKNMS provided valuable assistance with permitting. The manuscript contents are solely the opinions of the authors and do not constitute a statement of policy, decision, or position on behalf of NOAA or the US Government.

\section{Compliance with ethical standards}

Conflict of interest The authors declare they have no conflict of interest.

Ethical approval All applicable international, national, and/or institutional guidelines for the care and use of animals were followed.

Open Access This article is distributed under the terms of the Creative Commons Attribution 4.0 International License (http://creativeco mmons.org/licenses/by/4.0/), which permits unrestricted use, distribution, and reproduction in any medium, provided you give appropriate credit to the original author(s) and the source, provide a link to the Creative Commons license, and indicate if changes were made.

\section{References}

Alvarez-Filip L, Dulvy NK, Gill JA, Cote IM, Watkinson AR (2009) Flattening of Caribbean coral reefs: region-wide declines in architectural complexity. Proc R Soc B 276:3019-3025

Aronson RB, Precht WF (2001) White-band disease and the changing face of Caribbean coral reefs. Hydrobiologia 460:25-38

Brainard RE, Birkeland C, Eakin CM, McElhany P, Miller MW, Patterson M, Piniak GA (2011) Status review report of 82 candidate coral species petitioned under the US Endangered Species Act. US Dept Commer, NOAA Tech. Memo., NOAA-TM-NMFSPIFSC-27, 530 p. +1 Appendix 
Cantin NE, Lough NE (2014) Surviving coral bleaching events: Porites growth anomalies on the Great Barrier Reef. PLoS ONE 9(2):e88720

Chan NCS, Connolly SR (2013) Sensitivity of coral calcification to ocean acidification: a meta-analysis. Glob Change Biol 19:282-290

Courtney T, Westfield I, Ries JB (2013) $\mathrm{CO}_{2}$-induced ocean acidification impairs calcification in the tropical urchin Echinometra viridis. J Exp Mar Biol Ecol 440:169-175

Courtney TA, Andersson AJ, Bates NR, Collins A, Cyronak T, de Putron SJ, Eyre BD, Garley R, Hochberg E, Johnson R, Musielewicz S, Noyes TJ, Sabine CL, Sutton AJ, Toncin J, Tribollet A (2016) Comparing chemistry and census-based estimates of net ecosystem calcification on a rim reef in Bermuda. Front Mar Sci 3:181

Enochs IC, Manzello DP (2012) Species richness of motile cryptofauna across a gradient of framework erosion. Coral Reefs 31:653-661

Enochs IC, Manzello DP, Carlton R, Graham D, Ruzicka R, Collela M (2015) Ocean acidification enhances the bioerosion of a common coral reef sponge: implications for the persistence of the Florida Reef Tract. Bull Mar Sci 91:271-290

Enochs IC, Manzello DP, Kolodziej G, Noonan S, Fabricius K (2016a) Enhanced macroboring and depressed calcification drive net dissolution of coral reefs at $\mathrm{CO}_{2}$ seeps. Proc R Soc B 283:20161742

Enochs IC, Manzello DP, Tribollet A, Valentino L, Kolodziej G, Donham EM, Fitchett M, Carlton RD, Price NN (2016b) Elevated colonization of microborers at a volcanically acidified coral reef. PLoS ONE 11(7):e0159818

Eyre BD, Cyronak T, Drupp P, De Carlo EH, Sachs JP, Andersson AJ (2018) Coral reefs will transition to net dissolving before the end of the century. Science 359:908-911

Fang JKH, Schonberg CHL, Mello-Athayde MA, Hoegh-Guldberg O, Dove S (2014) Effects of ocean warming and acidification on the energy budget of an excavating sponge. Glob Change Biol 20:1043-1054

Fine M, Loya Y (2002) Endolithic algae: an alternative source of photoassimilates during coral bleaching. Proc R Soc B 269:1205-1210

Gardner TA, Côté IM, Gill JA, Grant A, Watkinson AR (2003) Long-term region-wide declines in Caribbean corals. Science 301:958-960

Gintert BE, Manzello DP, Enochs IC, Kolodziej G, Carlton RD, Gleason ACR, Gracias N (2018) Marked annual coral bleaching resilience of an inshore patch reef in the Florida Keys: a nugget of hope, aberrance, or last man standing? Coral Reefs. https://doi. org/10.1007/s00338-018-1678-x

Glynn PW (1988) El Nino warming, coral mortality and reef framework destruction by echinoid bioerosion in the eastern Pacific. Galaxea 7:129-160

Glynn PW (1990) Coral mortality and disturbance to coral reefs in the eastern tropical Pacific. In: Glynn PW (ed) Global ecological consequences of the 1982-83 El nino-southern oscillation. Elsevier, Amsterdam, pp 55-126

Glynn PW, Manzello DP (2015) Bioerosion and coral reef growth: a dynamic balance. In: Birkeland C (ed) Coral reefs in the anthropocene. Springer, Dordrecht, pp 67-97

Graham NAJ, Nash KL (2012) The importance of structural complexity in coral reef ecosystems. Coral Reefs 32:315-326

Groves S, Holstein D, Enochs I, Kolodziej G, Manzello DP, Brandt M, Smith TB (2018) Growth rates of Porites astreoides and Orbicella franksi in mesophotic habitats surrounding St. Thomas. Coral Reefs. https://doi.org/10.1007/s00338-018-1660-7

Guest JR, Low J, Tun K, Wilson B, Ng C, Raingeard D, Ulstrup KE, Tanzil JTI, Todd PA, Toh TC, McDougald D, Chou LM, Steinberg PD (2016) Coral community response to bleaching on a highly disturbed reef. Sci Rep 6:20717
Helmle KP, Kohler K, Dodge RE (2002) Relative optical densitometry and the coral X-radiograph densitometry system: Coral XDS. Int Soc Reef Studies 2002 European Meeting, Cambridge. http:// www.nova.edu/ocean/coralxds/index.html

Hudson JH, Shinn EA, Halley RB, Lidy B (1976) Sclerochronology: a tool for interpreting past environments. Geology 4:361-364

Kenkel CD, Matz MV (2016) Gene expression plasticity as a mechanism of coral adaptation to a variable environment. Nat Ecol Evol 1:0014

Kenkel CD, Goodbody-Gringley G, Caillaud D, Davies SW, Bartels E, Matz MV (2013) Evidence for a host role in thermotolerance divergence between populations of the mustard hill coral (Porites astreoides) from different reef environments. Mol Ecol 22:4335-4348

Kennedy EV, Perry CT, Halloran PR, Iglesias-Prieto R, Schonberg CHL, Wisshak M, Form AU, Carricart-Ganivet JP, Fine M, Eakin CM, Mumby PJ (2013) Avoiding coral reef functional collapse requires local and global action. Curr Biol 23:912-918

Lirman D, Fong P (2007) Is proximity to land-based sources of coral stressors an appropriate measure of risk to coral reefs? An example from the Florida Reef Tract. Mar Pollut Bull 54:779-791

Liu G, Strong AE, Skirving W, Arzayus LF (2006) Overview of NOAA coral reef watch program's near-real time satellite global coral bleaching monitoring activities. In: Proceeding 10th Int Coral Reef Symp 1:1783-1793

Loya Y, Sakai K, Yamazato K, Nakano Y, Sambali H, van Woesik R (2001) Coral bleaching: the winners and losers. Ecol Lett 4:122-131

Manzello DP (2015) Rapid recent warming of coral reefs in the Florida Keys. Sci Rep 5:16762

Manzello DP, Enochs IC, Melo N, Gledhill DK, Johns EM (2012) Ocean acidification refugia of the Florida Reef Tract. PLoS ONE 7:e41715

Manzello DP, Enochs IC, Kolodziej G, Carlton R (2015a) Recent decade of growth and calcification of Orbicella faveolata in the Florida Keys: an inshore-offshore comparison. Mar Ecol Prog Ser 521:81-89

Manzello DP, Enochs IC, Kolodziej G, Carlton R (2015b) Coral growth patterns of Montastraea cavernosa and Porites astreoides in the Florida Keys: the importance of thermal stress and inimical waters. J Exp Mar Biol Ecol 471:198-207

Miller MW, Bourque A, Bohnsack J (2002) An analysis of the loss of acroporid corals at Looe Key, Florida, USA: 1983-2000. Coral Reefs 21:179-182

Morgan KM, Perry CT, Johnson JA, Smithers SG (2017) Nearshore turbid-zone corals exhibit high bleaching tolerance on the Great Barrier Reef following the 2016 ocean warming event. Front Mar Sci 4:224

NOAA Coral Program (2014) National coral reef monitoring plan. NOAA coral reef conservation program. Silver Spring, MD, p 39

Pandolfi JM, Jackson JBC, Baron N, Bradbury RH, Guzman HM, Hughes TP, Kappel CV, Micheli F, Ogden JC, Possingham HP, Sala E (2005) Are U.S. coral reefs on the slippery slope to slime? Science 307:1725-1726

Perry CT, Morgan KM (2017) Bleaching drives collapse in reef carbonate budgets and reef growth potential on southern Maldives reefs. Sci Rep 7:40581

Perry CT, Edinger EN, Kench PS, Murphy GN, Smithers SG, Steneck RS, Mumby PJ (2012) Estimating rates of biologically driven coral reef framework production and erosion: a new census-based carbonate budget methodology and applications to the reefs of Bonaire. Coral Reefs 31:853-868

Perry CT, Murphy GN, Kench PS, Smithers SG, Edinger EN, Steneck RS, Mumby PJ (2013) Caribbean-wide decline in carbonate production threatens coral reef growth. Nat Comm 4:1-7 
Reyes-Nivia C, Diaz-Pulido G, Kline D, Hoegh-Guldberg O, Dove S (2013) Ocean acidification and warming scenarios increase microbioerosion of coral skeletons. Glob Chang Biol 19:1919-1929

Ruzicka RR, Colella MA, Porter JW, Morrison Kidney JA, Brinkhuis V, Lunz KS, Macaulay KA, Bartlett LA, Meyers MA, Colee J (2013) Temporal changes in benthic assemblages on Florida Keys reefs 11 years after the 1997/1998 El Niño. Mar Ecol Prog Ser 489:125-141

Shinn EA (1966) Coral growth-rate, an environmental indicator. J Paleontol 40:233-240

Silbiger NJ, Guadayol O, Thomas FI, Donahue MJ (2014) Reefs shift from net accretion to net erosion along a natural environmental gradient. Mar Ecol Prog Ser 515:33-44

Smith TB (2008) Temperature effects on herbivory for an Indo-Pacific parrotfish in Panama: implications for coral-algal competition. Coral Reefs 27:397-405
Tribollet A, Godinot C, Atkinson M, Langdon C (2009) Effects of elevated $\mathrm{pCO}_{2}$ on dissolution of coral carbonates by microbial euendoliths. Glob Biogeochem Cycles 23:1-7

Uthicke S, Liddy M, Nguyen HD, Byrne M (2014) Interactive effects of near-future temperature increase and ocean acidification on physiology and gonad development in adult Pacific sea urchin, Echinometra sp. A. Coral Reefs 33:831-845

van Woesik R, Houk P, Isechal AL, Idechong JW, Victor S, Golbuu Y (2012) Climate-change refugia in the sheltered bays of Palau: analogs of future reefs. Ecol Evol 2:2474-2484

Williams EH, Bunkley-Williams L (1990) The world-wide coral reef bleaching cycle and related sources of coral mortality. Atoll Res Bull 335:1-71

Wisshak M, Schonberg CHL, Form A, Freiwald A (2012) Ocean acidification accelerates reef bioerosion. PLoS ONE 7:e45124 